Abstracta Iranicacta Iranica

Revue bibliographique pour le domaine irano-aryen

Volume 27 | 2006

Comptes rendus des publications de 2004

\title{
«Borazjan, A Rural Market Town in Bushire's Hinterland ». Iran, 41 (2003), pp. 179-200.
}

\section{Rudi Matthee}

\section{OpenEdition}

1 Journals

\section{Édition électronique}

URL : http://journals.openedition.org/abstractairanica/5950

DOI : 10.4000/abstractairanica.5950

ISSN : 1961-960X

Éditeur :

CNRS (UMR 7528 Mondes iraniens et indiens), Éditions de l'IFRI

\section{Édition imprimée}

Date de publication : 15 mai 2006

ISSN : 0240-8910

\section{Référence électronique}

Rudi Matthee, « «Borazjan, A Rural Market Town in Bushire's Hinterland ». Iran, 41 (2003), pp. 179-200. ", Abstracta Iranica [En ligne], Volume 27 | 2006, document 168, mis en ligne le 02 janvier 2007, consulté le 25 septembre 2020. URL : http://journals.openedition.org/abstractairanica/5950 ; DOI : https://doi.org/10.4000/abstractairanica.5950

Ce document a été généré automatiquement le 25 septembre 2020.

Tous droits réservés 


\section{«Borazjan, A Rural Market Town in Bushire's Hinterland ». Iran, 41 (2003), pp. 179-200.}

\section{Rudi Matthee}

This study moves the focus of attention away from the Persian Gulf coast to the hinterland by analyzing the town of Borazjan in Qajar times, a market center of some 5,000 inhabitants located in the foothills some $45 \mathrm{~km}$ inland from Bushehr and, as the author argues, intimately connected with that port by being the regional distribution center. Using a plethora of sources, the article goes into the topography of the place, its ambient geography, its origins (obscure; the town was first mentioned only in 1786), demographics, its economy, and, above all its administrative structure and political vicissitudes in the course of the 19th and into the early 20th century, when newly established regional stability and road safety led to a brief commercial boom.

\section{INDEX}

Thèmes : 4.2.1. Safavides et Qâjârs

\section{AUTEURS}

RUDI MATTHEE

University of Delaware 